\title{
A Research on the Purchasing Intention of Chinese Consumer Finance
}

Tiantian Xia ${ }^{1, a}$, Yujie Liao ${ }^{2, b}$, Xiaomei Luo ${ }^{3, c}$ and Shangxin Chang ${ }^{4, d}$

${ }^{1}$ Tiantian Xia(1989-),Business School Netherlands Ph.D Candidates, Nanchang Institute of Technology Institute of Finance,Lecturer,Research field is Business management, Nanchang 330000, China

${ }^{2}$ Yujie Liao(1996-), Nanchang Institute of Technology Institute of Finance, Student, research field is Business Management,Nanchang 330000,China

${ }^{3}$ Xiaomei Luo(1994-), Nanchang Institute of Technology Institute of Finance, Student, research field is Business Management,Nanchang 330000,China

${ }^{4}$ Shangxin Chang(1982-), Nanchang Institute of Technology Institute of Finance,Lecturer, Research field is Business management, Nanchang 330000,China

a kidd1989730@qq.com , b553072670@qq.com

Keywords: Consumer Finance, Customer Perceived Value, Purchasing Intention, Brand Preference, Brand Trust

\begin{abstract}
In today's increasingly fierce market competition environment, consumer finance products will help to optimize the current loan pressure in China and improve market structure; At the same time,we concerned increase consumption to economic development, and thus achieve economic value increase. However, the academic research on consumer finance products, especially the research on consumers' purchasing intentions, is relatively scarce. This article first related definition, dimensions of consumer finance products of theoretical analysis, put forward to brand trust and brand preference as mediating effects and moderating effects, explores how consumer finance products customer perceived value impact on its intention to purchase the research model, by using SPSS 21.0 software for data analysis, to verify this hypothesis. This study improves the research on consumer finance products in China, and also discusses the main factors that influence the purchasing intention of consumers. It has practical significance and value.
\end{abstract}

\section{Introduction}

Under the current market conditions, consumer finance has become a part of China's market economy can not be ignored undoubtedly. As non-bank financial institutions to provide consumers with consumption for the purpose of business loans, consumer finance products has the characteristics of convenient and quick, not only can relieve each big enterprise demand for loans, helps drive the economic restructuring and change of the pattern of economic development in our country. To speed up the consumption structure upgrade,and to achieve sustainable economic growth, this has no doubt that choosing to purchase will guide role in whole construction machinery have made a lot of Consumer Finance[1]. And consumer finance products in our country as a new industry, what is deciding the consumers to their evaluation? And what is the influencing consumers' purchasing factors? This article through the purchasing intention of consumers for consumer finance products empirical studies, to define and understand the concept and essence of consumer finance products, in order to explore the main factors affecting consumer purchasing intention. 


\section{Theoretical Review and Research Hypothesis}

\section{(1) Customer perceived value and Purchasing intention}

Recently, many marketers and researchers have paid much attention to the perceived value, because the purchase of the product's perceived value plays an important role in the formation of the essence of the competitiveness and predict customer purchasing behavior (Bolton and Drew, 1991).Customer perceived value is usually considered to weigh the relative quality and relative prices (Gale, 1994). This concept is too simplistic, ignoring some important factors such as the risk of purchase, it will mislead the measurement of perceived value (Sinha and DeSarbo, 1998).Consumer finance products as the acting object, its most basic demand is to get customers to better return to buy such products, its function is to provide for the property buyers investment choice[2]. This forms the main factors of consumers purchase finance products to the customer perceived value, from the product the attribute to achieve its purchase goals and objectives, and to use the results of positive preference perceived and evaluated. This made the following assumptions:

H1: Consumers' perceived value quality of consumer finance products will have a significant positive impact on their buying intention.

(2) Mediating effects of brand trust

Many scholars have identity and trust related key elements of risk, no risk cannot reflect the trust,and consumer purchasing intention behavior choice is influenced by the perceived value. For example, Doney, Cannon (1997), and Moorman (1992), very stressed the concept of trust

must be associated with uncertainty the environment. Therefore, brand trust is often defined as " $\mathrm{A}$ state of mind in terms of 'perceived probability'”.In the cognitive basis, some scholars in different periods were defined. The definition of brand trust emphasize consumers in risk situations for brand performance expectations. If combined with the expected increase behavior point of view, Morris B Holbrook and Arjun Chaudhuri (2001) believes that brand trust is not only a consumer's desire to trust the brand, because it expects positive results, but also a willingness to rely on the brand's ability to carry out its claimed function[3]. This concept emphasizes consumers pay special attention to the claims made by the brand, and it also stressed that consumers pay more attention to whether the brand has the ability to achieve function; Therefore, brand trust is an important bridge between customer perceived value and purchasing intention. These conclude hypothesis two, hypothesis three and hypothesis four:

H2: Consumers' perceived value quality of consumer finance products will have a significant positive impact on their brand trust.

H3: Consumers' trust quality of consumer finance products will have a significant positive impact on their buying intention.

H4: Brand trust plays an intermediary role between customer perceived value and purchasing intention.

(3) Moderating effects of brand preference

Consumers will be more inclined to buy those they have experienced the benefits of the products or the people around them have already purchased the value of the products, and thus they prefer to buy this kind of consumer finance product. Zhang Hanyuan (2016) found in the study on purchasing intention of consumer finance products, the value of the experience of consumers through brand preference, will produce a certain degree of brand trust, and then promote the purchasing intention increased. Therefore, the consumers of finance products for perception, from the spiritual of brand reputation the experience, brand value evaluation, and affect their purchasing intention[4]. Thus, 
this paper puts forward the following assumptions:

H5: Brand preference plays a regulatory role between customer perceived value and purchase intention

In short, this article regard the brand trust as mediating effects, the brand preference as moderating effects, exploring effect between customer perceived value and purchasing intention. Analysis of the impact of the relevant variables on the purchasing intention theoretically, purchasing intention survey data were validated by different consumers[5]. The theoretical model is shown in Figure 1 below:

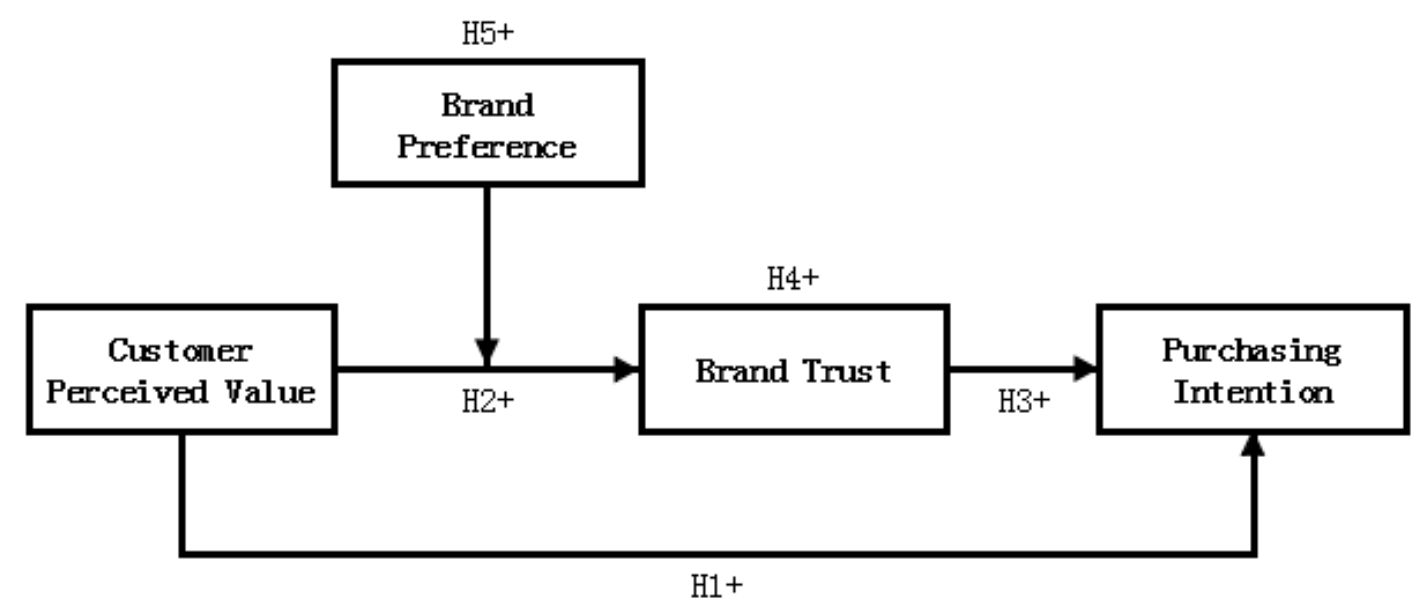

FIGURE 1 Proposed Mode1

\section{3 research variables and data analysis}

In the quantitative research and the scale of development, from the consumer perspective to explore the factors influencing the purchasing intention, usually the customer perceived value is one of the most important factors (Xia Tiantian,2016). Customer perceived value is the main consumer perception, brand trust and brand preference is also explored in recent years study on the variables of the most common factors affecting purchasing intention. According to the theory of consumer behavior, customer perceived value of good will have a certain degree of preference or trust in the purchasing of the brand, thereby increasing brand value. Therefore, this paper will take the customer perceived value as independent variables, brand trust and brand preference for mediating effects and moderating effects, purchasing intention as the dependent variable to carry out the research.

The questionnaire in this paper mainly consists of two parts, the first part is the demographic variables, such as age, sex, and education degree of these seven basic information. The second part is the study variables scale, which is based on the EFA analysis method, namely the four parts of customer perceived value, purchasing intention, brand trust and brand preference. The scale of this paper will mainly refer to Xia Tiantian(2016),Li Zubing (2015), Shen Lu (2016),Sun Yanling(2016) and other domestic scholars compiled relevant quantity.According to the research contents of this article after the formation of scale, using the Likert 7 scale to measure, from 1 to 7 means "completely disagree", "not agree" and "disagree", "general", "Relative agree", "agree" and "strongly agree", "Complete agreement". In order to accurately express the sample views and reduce the false and wrong answer, this article add the "uncertainty" item of 0.The study was conducted using a questionnaire survey,After passing with the research,Formal questionnaires were 
issued 450 copies,431 valid questionnaires were collected,The recovery was $95.78 \%$ And the demographic indicators are in line with relevant research standards.

(1) Exploratory factor analysis and reliability

This paper uses the Cronbach's a coefficient test of internal consistency reliability and validity. According to the results shown in Table $1, \mathrm{a}=0.955$ customer perceived value, KMO value $=0.954$, $\mathrm{P}<0.001$; Brand trust $\mathrm{a}=0.928, \mathrm{KMO}=0.899, \mathrm{P}<0.001 \mathrm{a}=0.927 \mathrm{KMO}$; Brand preference, value of $=0.904, \mathrm{P}<0.001 \mathrm{a}=0.911$; Purchasing intention, the value of $\mathrm{KMO}=0.879 \mathrm{P}<0.001$. At the same time, the research variables obtained from the factor load is higher than that of the standard. Therefore,it can be seen that the questionnaire prepared in this paper has better reliability and validity, and it is suitable for further study hypothesis verification.

TABLE 1 Exploratory factor analysis

\begin{tabular}{|c|c|c|c|c|c|c|c|c|c|}
\hline Variables & \multicolumn{2}{|c|}{ EFA } & KMO & Cronbach's a & Variables & \multicolumn{2}{|c|}{ EFA } & KMO & Cronbach's a \\
\hline \multirow{10}{*}{$\begin{array}{c}\text { Customer } \\
\text { Perceived } \\
\text { Value }\end{array}$} & X1 & 0.911 & \multirow{10}{*}{$\begin{array}{c}0.954 \\
* * *\end{array}$} & \multirow{10}{*}{0.955} & \multirow{5}{*}{$\begin{array}{c}\text { Brand } \\
\text { Preference }\end{array}$} & W1 & 0.879 & \multirow{5}{*}{$\begin{array}{c}0.904 \\
* * *\end{array}$} & \multirow{5}{*}{0.927} \\
\hline & X2 & 0.818 & & & & W2 & 0.887 & & \\
\hline & X3 & 0.842 & & & & W3 & 0.902 & & \\
\hline & X4 & 0.852 & & & & W4 & 0.846 & & \\
\hline & X5 & 0.859 & & & & W5 & 0.888 & & \\
\hline & X6 & 0.857 & & & \multirow{10}{*}{$\begin{array}{l}\text { Purchasing } \\
\text { Intention }\end{array}$} & & & & \\
\hline & X7 & 0.808 & & & & & & & \\
\hline & X8 & 0.796 & & & & & & & \\
\hline & X9 & 0.845 & & & & & & & \\
\hline & X10 & 0.863 & & & & & & 0.879 & \\
\hline \multirow{5}{*}{ Brand Trust } & M1 & 0.895 & \multirow{5}{*}{$\begin{array}{c}0.899 \\
* * *\end{array}$} & \multirow{5}{*}{0.928} & & & & $* * *$ & \\
\hline & M2 & 0.882 & & & & & & & \\
\hline & M3 & 0.895 & & & & & & & \\
\hline & M4 & 0.872 & & & & & & & \\
\hline & M5 & 0.861 & & & & & & & \\
\hline
\end{tabular}

** $\mathrm{P}<0.01, \quad * * * \mathrm{P}<0.001$

(2) Correlation analysis

In this section, the correlation analysis between the customer perceived value, brand trust, brand preference and purchasing intention of Consumer Finance is analyzed through correlation analysis. The specific results are shown in table 2. According to table 2 analysis data, the correlation coefficient between customer perceived value and purchasing intention is 0.886 , and $\mathrm{P}$ is significant at above 0.01 . The correlation coefficient between brand trust and purchasing intention was 0.854 , and $\mathrm{P}$ was significant at above 0.01. The correlation coefficient between brand preference and purchasing intention was 0.863 , and $\mathrm{P}$ was significant at above 0.01 . 


\section{(3) The comprehensive effect analysis}

Customer perceived value influences consumers' purchasing intention of consumer finance products through brand trust, and brand preference plays a moderating role in the relationship between customer perceived value and purchasing intention. At the same time, brand trust as the mediating effects is influenced by the moderating effects of brand preference.Therefore, this paper uses hierarchical regression the methods of hypothesis to test, the test results are shown in Table 2 . According to the test results of the model 1 and model 2, we can know that the customer perceived value has significant positive influences between customer perceived value, brand trust and purchasing intention, Verifying hypothesis H1, H2, and H3; The purchasing intention in model 3 is the regression result data of customer perceived value, brand trust and brand preference, Adj $\mathrm{R} 2=0.861, \mathrm{P}<0.001, \mathrm{~F}=27.534$. In short, the brand trust has positive influence on the purchasing intention.To Verify the hypothesis H4 is significant in the mediating effect of brand trust[6]. At the same time, the purchasing intention in model 4 shows the regression result data of customer perceived value, brand trust, brand preference, brand trust multiply brand preference,Adj R2 $=0.872$, $\mathrm{P}<0.001, \mathrm{~F}=26.367$. Therefore, brand trust multiply brand preference has a positive impact effect on purchasing intention. This indicates that brand preference plays a moderating role between customer perceived value and purchasing intention of brand preference is significantly positive in the relationship. The brand preference is established to verify hypothesis H5.

TABLE 2 Integration Effect Analysis

\begin{tabular}{|c|c|c|c|c|}
\hline Variables & $\begin{array}{c}\text { Mode1 } 1 \\
\text { Purchasing } \\
\text { Intention } \\
\text { Beta }\end{array}$ & $\begin{array}{c}\text { Mode1 } 2 \\
\text { Brand Trust } \\
\text { Beta }\end{array}$ & $\begin{array}{c}\text { Mode1 } 3 \\
\text { Purchasing } \\
\text { Intention } \\
\text { Beta }\end{array}$ & $\begin{array}{c}\text { Mode1 } 4 \\
\text { Purchasing } \\
\text { Intention } \\
\text { Beta }\end{array}$ \\
\hline Customer Perceived Value & $0.543 * * *$ & $0.286 * * *$ & $0.473 * * *$ & $0.472 * * *$ \\
\hline Brand Preference & $0.425 * * *$ & $0.631 * * *$ & $0.270 * * *$ & $0.273 * * *$ \\
\hline Brand Trust & & & $0.244 * * *$ & $0.246 * * *$ \\
\hline Brand Trust $\times$ Brand Preference & & & & $0.104 * *$ \\
\hline $\mathrm{R}^{2}$ & $0.921 * * *$ & $0.879 * * *$ & $0.928 * * *$ & $0.938 * * *$ \\
\hline $\operatorname{Adj} R^{2}$ & 0.848 & 0.772 & 0.861 & 0.872 \\
\hline $\mathrm{F}$ & 26.212 & 45.216 & 27.534 & 26.367 \\
\hline
\end{tabular}

$* * \mathrm{P}<0.01, \quad * * * \mathrm{P}<0.001$

\section{Conclusion}

(1) The conclusion of the study

There is a significant positive correlation between consumer perceived value, brand trust and purchasing intention of consumer finance products, which is consistent with most previous research results ; Brand trust between customer perceived value and purchasing intention is play a completely mediating role. This was partly due to the customer when buying consumer finance products tend to be more inclined to buy those products which they are familiar with before. This survey sample, on the other hand, middle-class incomes to buy intention accounts for more than 
73.1\%, for their own investment or consumption tend to be conservative. But at the same time with the researchers view, the consumers' perception of the demand of a consumer finance product is of great importance to the brand reputation and brand value experience.

(2) Marketing suggestions

For finance products companies, they could strengthen those who make good sense of customers,and improve staff skills training. Learning more heterogeneous knowledge about this kind of product information, in order to have more practical information for the customers and product function. In this way, we could enhance the purchasing intention of consumers for their products. Another way to strengthen consumer buy consumer finance products is increasing the spread of the knowledge of the consumer finance products, making people can learn how to use their money to invest reasonable consumption. Consequently driving the circulation for the economic growth and promoting national economic transformation. Finally,everybody should take corresponding measures to improve consumer finance products attractive includes the government, society and industry, prompting consumers to the cognition of finance products and learning.It is the key to the sustainable development of consumer finance products.

\section{References}

[1]Zhang xueyong.A summary of the third China Symposium on consumer finance[J].Economic Research Journal,2014,49(S1):189-192. [2017-08-03].

[2]Xia Tiantian.A Study of the Impact of Customer Percelved Value on Purchas Intention in Herhal Tea Market Context[D].Jiangxi Normal University.2016.

[3]Xin Chong,Guo Xin,Zhou Yushi.Influence of Electronic Word of Mouth Marketing via Social Networking Website on Consumers' Group-buying Intention:Considering Mediating Effect of Brand Trust[J].Technology Economics,2016,35(10):102-109. [2017-08-03].

[4]Zhang Hanyuan.The Internet Strategy Research In Retail Financial For Bank Of Dalian[D]. Southwestern University of Finance and Economics.2016.

[5]Li Zubing. The impact study of customer perceived value on herbal tea consumers' brand preference and purchase intention[D].South China University of Technology. 2012.

[6]WEN Zhonglin, YE Baojuan.Analyses of Mediating Effects: The Development of Methods and Models[J].Advances in Psychological Science 2014, Vol.22, No.5, 731-745, 